\title{
An oviposition trap to collect immatures of coprophagous moth flies (Diptera: Psychodidae)
}

\author{
DAYANA A. LIMA, DANILO P. CORDEIRO \& ELIZABETH FRANKLIN
}

\begin{abstract}
Larvae of Psychodidae develop in a variety of breeding sites, including vertebrate feces. As searching for the larvae can be an extremely difficult task, immatures of many species are little known, with descriptions of coprophagous moth flies all from outside the Neotropics. In an attempt to mitigate this challenge, we tested an oviposition trap using cattle dung as attractant, measured the efficiency and specificity of the traps and the most efficient period of exposition in the field. With 60 traps installed in one fragment of ombrophilous forest, 344 immatures were collected, distributed in four species of Psychoda and one of Feuerborniella. Psychodidae accounted for $75 \%$ of the collected Diptera. The high specificity of the trap to Psychodidae contrasts with other studies on coprophagous fauna where they appear in low abundance. Based on the metrics in this study, the most efficient period of trapping exposition was between five to eight days, but the difference was not significant probably due to the high number of zero observations among the traps. Many questions pertaining to coprophagous moth flies remain unanswered. Further research is needed to improve trapping efficiency, elucidate the effects of attractants and determine how environmental factors influence the attractiveness of bait.
\end{abstract}

Key words: cattle-Arthropoda, immature insects, Psychodinae, sampling efficiency.

\section{INTRODUCTION}

Larvae of Psychodidae can be found in a variety of breeding sites like soil, rotting wood, decaying organic material, moss carpets, fresh water streams, shallow rivers and phytotelmata (Wagner \& Ibáñez-Bernal 2009). The immature stages of many moth flies remain undescribed or poorly known mainly in the Neotropics. This is due in part to the difficulty of finding their natural breeding sites, as well as challenges involved with rearing psychodids in the laboratory (Ward 1972, Omad et al. 2013).

Coprophagous larvae of Psychodidae have been found in vertebrate feces, although this habit seems to be restricted to few genera and species of Psychodini (Wagner 1997). Knowledge regarding immatures of coprophagous Psychodidae is incipient, with larvae described for only a few Psychoda species from the United Kingdom (Satchell 1947) and New Zealand (Goldson 1977). Despite the fact that moth flies are frequently reported in studies with coprophagous fauna (Valiela 1974, Cervenka \& Moon 1991, Macedo et al. 2001), they are usually recorded in low abundance when compared to other taxa inhabiting fecal masses.

Effective monitoring is necessary to manage moth flies, but suitable attractants and the time of exposition in the field are still being identified. In the interest of overcoming barriers to improving our knowledge of coprophagous moth flies, we describe the attractiveness 
and efficiency of an oviposition trap to collect immatures of coprophagous moth flies (Diptera: Psychodidae) and test the period of trap activity in the field.

\section{MATERIALS AND METHODS}

\section{Areas of study}

The study was performed at Reserva Ducke, located on the limits of Manaus, Brazil $\left(3^{\circ} 05^{\prime} \mathrm{S}\right.$, $60^{\circ} 00^{\prime} \mathrm{W}$ ) and with an area of 10,000 hectares (100 $\mathrm{km}^{2}$ ) of dense ombrophilous tropical rain forest relatively undisturbed, which has topographic and edaphic variations typical of many areas in central Amazônia. There are approximately 1,200 species of trees (Costa et al. 2009) with a canopy height of 30-37 m, and some emergent reaching 40-45 m (Ribeiro et al. 1999).

\section{Trap}

The oviposition trap was constructed with one black plate (to accommodate the attractive material), the superior $1 / 3$ of one $2.5 \mathrm{~L}$ pet bottle painted with black ink (to protect the material from rain and larger animals) and one transparent $0.5 \mathrm{~L}$ pet bottle (to collect adults) (Figure 1). The plate holding the attractive material was linked by wires to the superior $1 / 3$ of the larger bottle, leaving a passageway approximately $1 \mathrm{~cm}$ wide. This structure was coupled with the small transparent bottle by a trimmed $1.5 \mathrm{~mL}$ microvial, allowing the transit of adults to the transparent bottle. A hook was fixed on the top of the trap, which was then suspended by a string. On each trap, approximately $1.5 \mathrm{~cm}^{3}$ of cattle dung (Bos taurus Linnaeus, 1758) was used as an oviposition site.

The cattle dung was collected on the municipality of "Careiro da Várzea", 29 km from Manaus, right after expelled by the animal, kept on a sealed vessel to avoid colonization by insects and transported to the experiment site in
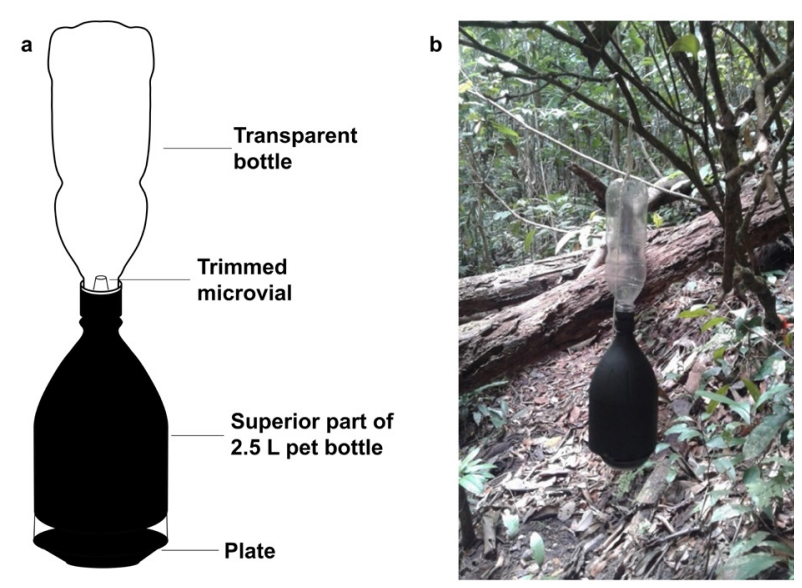

Figure 1. (a) Oviposition trap for the capture of coprophagous moth flies. (b) Trap placed in the field.

approximately four hours. Thus, trap exposition period is equivalent to the decomposition period of the feces, as they were collected on the same day of the experiment setup.

At Reserva Ducke, 30 traps were installed from 15 to 25 of October and from 9 to 19 of December 2016. At each $24 \mathrm{~h}$ three traps were randomly selected and taken to the laboratory in Manaus for later sorting and identification. All traps were suspended approximately $50 \mathrm{~cm}$ from the ground and $100 \mathrm{~m}$ distant from each other, nine following a trail on the side of a stream called Igarapé Barro Branco, and 21 following a trail that is at least $50 \mathrm{~m}$ distant from the stream.

In the laboratory in Manaus, the collected material was kept on a vessel sealed with plastic film for three days to allow eclosion of larvae in the case of oviposition by moth flies. After three days, the fecal mass was inspected on a stereoscopic scope, and the living immatures were individualized until adult stage for species identification. Adults, dead larvae, pupae, and exuviae of larvae and pupae were preserved in $70 \%$ ethanol. Species were identified by the emerged adults, using key of Cordeiro et al. (2011) and original descriptions (Edwards 1928, Quate 1996, Bravo et al. 2006 and Cordeiro et al. 
2011). All voucher material is deposited at the Entomological Collection of INPA. To evaluate the correlation between the period of trap exposition and Psychodidae abundance we estimated the Pearson correlation coefficient.

\section{RESULTS AND DISCUSSION}

From the 60 installed traps, we obtained 460 immature individuals belonging to Diptera. Psychodidae reached the abundance of $75.8 \%$ of the collected Diptera. Five Psychodini species were collected (Table I): Psychoda litotes Quate, 1996, Psychoda savaiiensis Edwards, 1928, Psychoda atlantica Cordeiro et al. 2011, Psychoda serraorobonensis Bravo et al. 2006 and Feuerborniella sp.

Among the 60 traps, 16 presented Psychodidae immatures, taken between the exposition period of 72-240 h (3-10 days) (Figure 2). None of the traps with an exposition period inferior to $72 \mathrm{~h}$ were positive for Psychodidae. Although $74.7 \%$ of the Psychodidae were collected on traps exposed for five to eight days, the difference was not significant (Pearson $r=0.518 ; p=0.125$ ), probably because of a high number of zero observations among the traps (Figure 2). A higher proportion of positive observations were recorded when comparing traps installed on the margin of the water stream with traps installed far from the stream (50\% and $16.7 \%$, respectively).

The trap was also designed to collect adults, but it failed on this purpose as no insect's adult was collected in the superior part of the trap. For future studies we suggest the trap can be simplified, excluding the superior transparent bottle designed to collect adults.

The efficiency of the oviposition trap to collect moth flies in detriment of other Diptera, contrasts with other studies with coprophagous
Table I. Diversity of moth flies collected with oviposition traps in 2016.

\begin{tabular}{|c|c|c|}
\hline & October & December \\
\hline Psychoda litotes & 50 & 198 \\
\hline Feuerborniella sp. & 41 & 0 \\
\hline Psychoda atlantica & 0 & 25 \\
\hline Psychoda savaiiensis & 0 & 17 \\
\hline Psychoda serraorobonensis & 0 & 13 \\
\hline
\end{tabular}

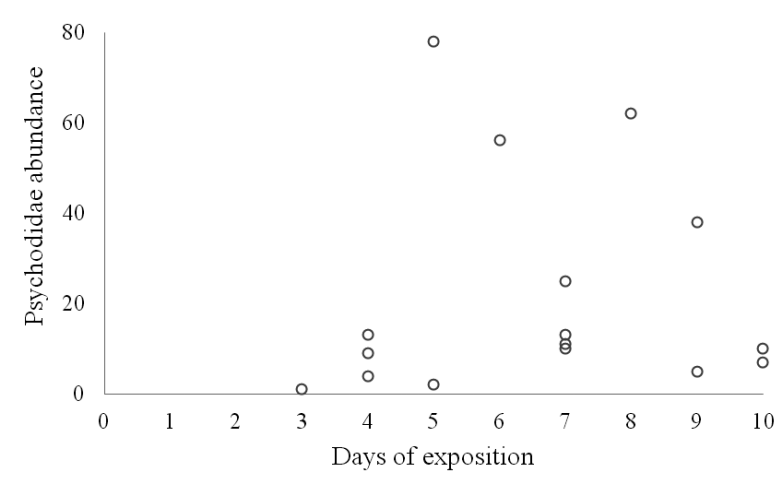

Figure 2. Total abundance of Psychodidae adults collected during October and December 2016 on 60 oviposition traps in relation to the fecal decomposition period (days of exposition).

fauna. On a survey carried out in a cattle farm of "Campinas" municipality in São Paulo State, immature Psychodidae abundance in cattle dung was only $0.18 \%$ (M.M.G. Amaral, unpublished). On that study, immatures of Psychodidae were also not found in cattle dung plates exposed by only $24 \mathrm{~h}$. Collecting adults and larvae associated to cattle dungs at a cattle farm in Malaysia, Chin et al. (2010) recorded an abundance of $5.2 \%$ Psychodidae in relation to the total Diptera. In these two previous studies, insects were collected on cattle droppings, which attract many other flies in larger density, mainly Sepsidae and Muscidae.

This experiment brings to light the attractiveness of adults of Psychodidae species for cattle dung, with no previous biological data on the literature. The trap showed a 
high specificity in collecting the immatures of Psychodidae. However, further studies using this trap are necessary to test the best location and optimal time of exposition in the field in order to collect a representative part of the community. The amount and type of substrate should be tested to optimize the attractiveness of the trap. Together, these elements can improve the efficiency of studies of moth flies, facilitate the acquisition of specimens for both taxonomic and ecological investigations, and save time and cost in environmental assessment.

\section{Acknowledgments}

We are grateful for the contributions of Gregory Curler and Rüdiger Wagner who have reviewed the manuscript. We want to thank Coordenação de Aperfeiçoamento de Pessoal de Nivel Superior (CAPES) for the fellowship of Dayana Andrade de Lima and Danilo Pacheco Cordeiro.

\section{REFERENCES}

BRAVO F, CORDEIRO DP \& CHAGAS C. 2006. Two new species and new records of Psychoda Latreille (Diptera: Psychodidae: Psychodinae) from Brazil, with comments on supraspecific classification of the genus. Zootaxa 1298: 1-15.

CERVENKA VJ \& MOON RD. 1991. Arthropods Associated with Fresh Cattle Dung Pats in Minnesota. J Kans Entomol Soc 64(2): 131-145.

CHIN HC, AHMAD NW, KIAN CW, KURAHASHI H, JEFFERY J, KIANG HS \& OMAR B. 2010. A Study of Cow Dung Diptera in Sentul Timur, Kuala Lumpur, Malaysia. J Trop Med Parasitol 33(2): 53-61.

CORDEIRO DP, BRAVO F \& CARVALHO CJB. 2011. Taxonomy of Brazilian Psychoda Latreille, 1796 (Diptera, Psychodidae) with the description of thirteen new species. Zootaxa 3101: 1-37.

COSTA FRC, JEAN-LOUIS G, LIMA A \& PEREIRA OS. 2009. Gradients within gradients: the mesoscale distribution patterns of palms in a central Amazonian forest. J Veg Sci 20: 67-78.

EDWARDS FW. 1928. Insects of Samoa and other samoan terrestrial Arthropoda. British Museum (Natural History) 6(2): 1-102.
GOLDSON SL. 1977. Larvae of four New Zealand species of Psychoda (Dipera: Psychodidae). N Z Entomol 6(3): 279-284.

MACEDO DM, BRITO LG \& BORJA GEM. 2001. Emergência de Haematobia irritans em fezes bovinas no município de Seropédica, Rio de Janeiro. Pesq Vet Bras 21: 77-80.

OMAD GH, MANGUDO C, ANJOS-SANTOS D \& GLEISER RM. 2013. Descriptions of Pupae of Three Psychodinae Species (Diptera: Psychodidae) from Argentina. Annal Zool 3(3): 401-408.

QUATE LW. 1996. Preliminary taxonomy of Costa Rican Psychodidae (Diptera), exclusive of Phlebotominae. Rev Biol Trop 44(1): 1-81.

RIBEIRO JELS ET AL. 1999. Flora da Reserva Ducke: Guia de Identificacão das Plantas Vasculares de uma Floresta de Terra-firme na Amazônia Central. Manaus: Instituto Nacional de Pesquisas da Amazônia (INPA) and Department for International Development (DFID), 816 p.

SATCHELL GH. 1947. The larvae of the British species of Psychoda (Diptera: psychodidae). Parasitology 38(51): 51-69.

VALIELA I. 1974. Composition, Food Webs and Population Limitation in Dung Arthropod Communities During Invasion and Succession. Am Midl Nat 92(2): 370-385.

WAGNER R. 1997. Family Psychodidae. In: Papp L and Darvas B (Eds), Contributions to a Manual of Palaeartic Diptera. Vol.2: Nematocera and Lower Brachycera, Budapest, Science Herald, p. 205-226.

WAGNER R \& IBÁÑEZ-BERNAL S. 2009. Psychodidae. In: Brown BV, Borkent A, Cumming JM, Wood DM, Woodley NE and Zumbado MA (Eds), Manual of Central American Diptera, Ottawa, National Research Council Press 1: 9-502.

WARD RD. 1972. Some observations on the biology and morphology of the immature stages of Psychodophygus Wellcomei Fraiha, Shaw and Lainson, 1971. (Diptera: Psychodidae). Mem Inst Oswaldo Cruz 70: 15-28.

\section{How to cite}

LIMA DA, CORDEIRO DP \& FRANKLIN E. 2020. An oviposition trap to collect immatures of coprophagous moth flies (Diptera: Psychodidae). An Acad Bras Cienc 92: e20181093. DOI 10.1590/0001-3765202020181093.

Manuscript received on October 17, 2018; accepted for publication on December 27, 2018 
DAYANA A. LIMA ${ }^{1}$

https://orcid.org/0000-0003-3859-9533

DANILO P. CORDEIRO ${ }^{1,2}$

https://orcid.org/0000-0002-3085-8628

\section{ELIZABETH FRANKLIN ${ }^{1}$}

https://orcid.org/0000-0001-8485-6743

${ }^{1}$ Coordenação de Biodiversidade, Instituto Nacional de Pesquisas da Amazônia, Campus II, Aleixo, Av. André Araújo, 2936, 69011-970 Manaus, AM, Brazil

${ }^{2}$ Instituto Nacional da Mata Atlântica, Av. José Ruschi, Centro, 04, 29650-000 Santa Teresa, ES, Brazil

Correspondence to: Danilo Pacheco Cordeiro

E-mail:d.pacheco.c@gmail.com

\section{Author contributions}

Dayana Andrade de Lima contributed on the field and lab work, writing of the manuscript and analysis of data; Danilo Pacheco Cordeiro participated on fieldwork, identified the specimens and contributed to writing of the manuscript and analysis of data; Elizabeth Franklin contributed to the analysis of data and writing of the manuscript.

(cc) $\mathbf{B Y}$ 